Egyptian Journal of Aquatic Biology \& Fisheries

Zoology Department, Faculty of Science,

Ain Shams University, Cairo, Egypt.

ISSN $1110-6131$

Vol. 24(6): 469 - 478 (2020)

www.ejabf.journals.ekb.eg

\title{
Chromosomal Studies on the Egyptian Fresh Water Snail Biomphalaria alexandrina by using Transmission and Scanning Electron Microscope
}

\author{
Samah I. Ghoname ${ }^{1^{*}}$, Amira H. Mohamed $^{2}$ and Shadia M. El- Dafrawy ${ }^{1}$ \\ 1-Depart. of Environmental Research and Medical Malacology, Theodor Bilharz Research \\ Institute, Egypt. \\ 2- Depart. of Electron Microscopy,Theodor Bilharz Research Institute P.O. Box 30, Imbaba, \\ Giza, Egypt \\ *Corresponding Author: samah.ghoname@gmail.com
}

\section{ARTICLE INFO}

Article History:

Received: Aug. 25, 2020

Accepted: Sept. 28, 2020

Online: Oct. 4, 2020

Keywords:

B. alexandrina, meiotic division,

SEM,

TEM,

chromosome.

\section{ABSTRACT}

The present study is an approach to investigate the chromosomal pattern of Biomphalaria alexandrina snails. This may be useful for breaking the hostparasite relationship, which is very specific and dependable on the genetic (chromosomal) status of these hosts. Freshwater snails are essential for the transmission of schistosomiasis by acting as intermediate hosts for the diseasecausing parasite. The objective of this study clarifies the four meiotic divisions that begin with Interphase, prophase, metaphase, and anaphase by Transmission Electron Microscope (TEM) and measuring the lengths of chromosomes by Scanning Electron Microscope (SEM). Results showed the number of the chromosomes of $B$. alexandrina snails $\mathrm{N}=18,2 \mathrm{~N}=36$ including 4 types of chromosomes, 5 metacentric pairs, 4 submetacentric pairs, 3 acrocentric pairs, and 6 telocentric pairs chromosomes, they were arranged in a descending manner according to the total length that between 12-2 $\mu \mathrm{m}$. Notably, the present work is the first chromosomal study of $B$. alexandrina snails by using TEM and SEM. So high-resolution SEM has proven to be a useful tool for chromosomal study.

\section{INTRODUCTION}

Schistosomiasis is a chronic parasitic disease caused by a trematode blood fluke of the genus Schistosoma which belongs to the Schistosomatidae family, namely, Schistosoma mansoni, S. haematobium, $S$. intercalatum, $S$. mekongi, and $S$. japonicum (Gryseels, 2006). This parasite mostly affects developing countries; it infects over 240 million people in about 78 countries, primarily in Africa (Colley et al., 2014), with high prevalence in Egypt (El-Sheikh $\boldsymbol{e t}$ al., 2012). Schistosomiasis is the second most widespread human parasitic disease next to malaria (CDC, 2018). Schistosomiasis still a public health problem that impact the life of millions worldwide (Toor et al., 2018). WHO's work on schistosomiasis is part of an integrated approach to the control of neglected tropical diseases (NTDs) and coordinates the strategy of preventive chemotherapy in consultation with collaborating centers and partners from academic and 
research institutions (WHO, 2020). Family Planorbidae had bulky morphological range and hence it is very interesting in studying the cytogenetic variations (Szabelska $\boldsymbol{e t}$ al., 2015) and used in methodical analysis of freshwater snails (Tohamy and Mohamed, 2006). The chromosomal number can be used in differentiating one species from another, that is the analysis of chromosome numbers, size, and centromere positions (ThiriotQuiévreu, 2003 and Odoemelam, 2009). Karyotyping (organising chromosomes into groups in accordance with size and morphology) is a useful tool for studying taxonomic problems such as identifying species as unique from another within the same subgenus (Hamta et al., 2006).

\section{MATERIALS AND METHODS}

Clean B. alexandrina snails were taken alive from laboratory-bred stock of the Medical Malacology, Theodor Bilharz Research Institute (TBRI), then maintained in tanks of aerated water and fed continuously to promote growth. Chromosome preparation were obtained from the ovotestis of the snails. Preparation of chromosomes in snails were made according to the method described by Barsiene $\boldsymbol{e t}$ al. (2000). Pooled snails (about 10 snails for each sample) were placed directly in $0.1 \%$ colchicine at room temperature, for one day. Snails were dissected and ovotestis separated then carefully minced in $0.48 \%$ $\mathrm{KCl}$ as hypotonic solution at room temperature and transferred to centrifuge tubes where they were left for 1.5- 2 hours, after which they were centrifuged for 10 minutes at 2500 rpm.

\section{Transmission Electron Microscope Methods}

Technical Procedure: The samples were centrifuged then the pellets were immediately processed according to Glauert (1974). The pellets were immediately fixed in $2.5 \%$ glutaraldehyde in PBS for 30 minutes at room temperature (RT), washed three times in PBS and post fixed in $1 \%$ osmium tetroxide $\left(\mathrm{OsO}_{4}\right)$ in PBS for 30 minutes at $4^{\circ} \mathrm{C}$. This was followed by dehydration in ascending grades of ethyl alcohol, substitution in epon/ethanol mixture (1:1) for one hour, infiltration in 3 overnight baths of epon at RT and finally embedded in epon capsules which were polymerized at $37^{\circ} \mathrm{C}$ for 12 hours and at $60^{\circ} \mathrm{C}$ for 2 days. Ultrathin sections were collected on copper grids then the grids with sections were stained by 4, 6-diamidino-2-phenylindole (DAPI), used as a useful stain for 15 minutes to visualize nuclear DNA in fixed cells, then washed three times in DW and finally examined by (EM 208S Philips,Netherlands). Electron Microscope at Electron Microscopy Unite of Theodor Bilharz Research Institute (TBRI).

\section{Scanning electron microscope}

Technical Procedure: The sample were fixed in equal volumes of glutaraldehyde $4 \%$ and Cacodylate $0.2 \%$ for 2 hours, it was then washed in equal volumes of Sucrose $0.4 \%$ and Cacodylate $0.2 \%$ for 2 hours. Post fixed in equal volumes of osmic acid $2 \%$ and Cacodylate $0.3 \%$ for 1 hour, washed with distilled water, finally dehydrated in ascending grades of ethyl alcohol for 5 min each $(30 \%, 50 \%, 70 \%$ and $90 \%)$ then absolute alcohol 100\% for 10 min for 3 times (Glauert, 1974), and finally examined by Environmental SEM (ESEM) which is the development of a normal high-vacuum SEM (Inspect S; FEI,Holland) at Electron Microscopy Unite of Theodor Bilharz Research Institute (TBRI). 


\section{Statistical analysis}

The results were presented as the means $\pm \mathrm{SE}$, statistical analyses were performed using JMP ver. 12.0 (SAS Institute Inc., Cary, NC, USA). The number of chromosome was reported complications corresponding percentage $(\%)$ for nominal variables.

\section{RESULTS}

\section{Transmission Electron Microscope Examination}

TEM allows the accurate study of four meiotic phases: interphase, prophase, metaphase and anaphase. In interphase the chromosomes appear more condensed and coil (Fig. 1-A) and the chromosome in prophase are connected by chromatin threads in (Fig. 1-B), Fig. (1-C) showed chromosomes in metaphase as bundled at the centrometric regions. In anaphase the chromosomes spread and appear as a curved shape (Fig.1-D).

A

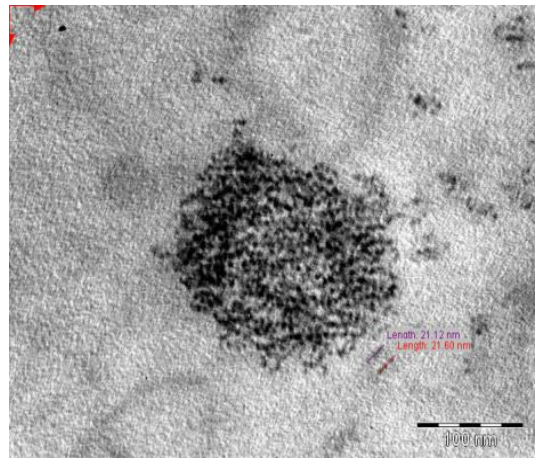

$\mathrm{C}$

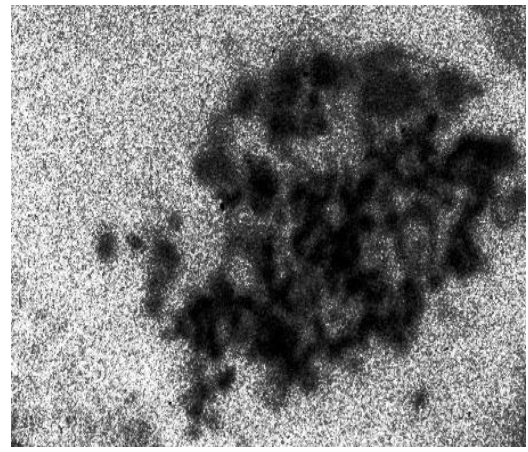

B

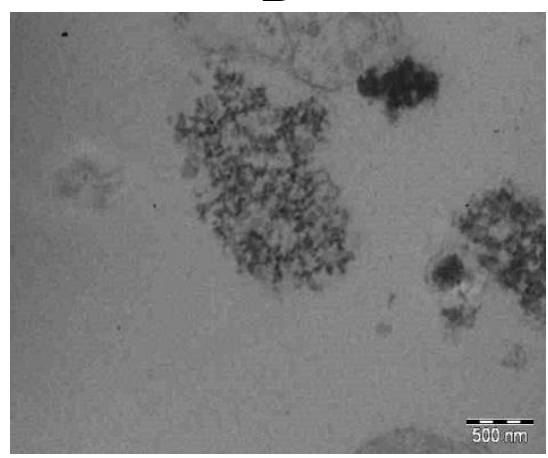

$\mathrm{D}$

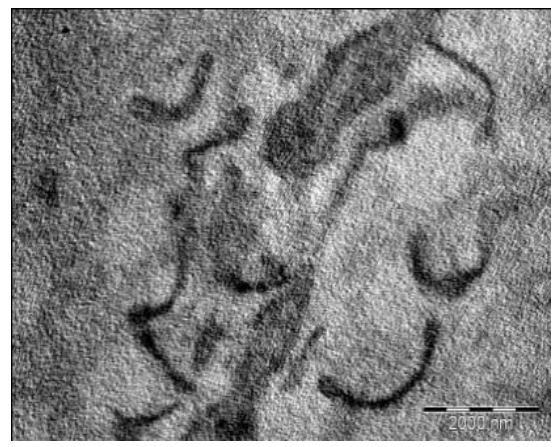

Fig. 1. Electron micrograph of Biomphalaria alexandrina snails showing the chromosomes stained with DAPI in the four mieotic phase. A: Showed chromosomes in interphase they appear condensed with dark polar oriented heterochromatic regions. B: Showed chromosomes in prophase the chromosome become more smooth but some are still connected by chromatin threads. C: Showed chromosomes in metaphase chromosomes still bundled at the centrometric regions but free at telemetric with varies length. D: Showed chromosomes in anaphase chromosomes speared and appear curved with construction at the centromere between short and long arm. 


\section{Scanning Electron Microscope Examination}

The current results showed a haploid number of chromosomes $n=18$ arranged in a descending manner according to the total length that between 12-2 $\mu \mathrm{m}$ (Table 1 and Fig 2, 3 (A-E). There are four types of chromosomes in B. alexandrina: Five chromosomes are metacentric with ranging between $12-10.5 \mu \mathrm{m}$, four submetacentric with ranging between $8.2-6.2 \mu \mathrm{m}$, three acrocentric with ranging between 5.5- $4.2 \mu \mathrm{m}$ and the last 6 telocentric with ranging between $4.1-2 \mu \mathrm{m}$.

Table 1. Measurements and classification of chromosomes $(n=18)$ of Biomphalaria alexandrina snails.

\begin{tabular}{|c|c|c|c|c|c|c|}
\hline $\begin{array}{c}\text { Chromosome } \\
\text { number }\end{array}$ & Classification & $\begin{array}{c}\text { Long } \\
\operatorname{arm}(\mu \mathrm{m})\end{array}$ & $\begin{array}{c}\text { Short } \\
\operatorname{arm}(\mu \mathrm{m})\end{array}$ & $\begin{array}{c}\text { Total } \\
\text { length }(\mu \mathrm{m})\end{array}$ & $\begin{array}{c}\text { Relative length } \\
\text { (\%) }\end{array}$ & Arm ratio \\
\hline & & Mean \pm SE & Mean \pm SE & Mean \pm SE & Mean \pm SE & Mean \pm SE \\
\hline 1 & Metacentric & $6.1 \pm 0.14$ & $5.9 \pm 0.14$ & $12 \pm 0.19$ & $9.97 \pm 0.09$ & $1.03 \pm 0.007$ \\
\hline 2 & Metacentric & $6.4 \pm 0.07$ & $5.5 \pm 0.06$ & $11.9 \pm 0.18$ & $9.88 \pm 0.06$ & $1.16 \pm 0.009$ \\
\hline 3 & Metacentric & $6.3 \pm 0.15$ & $5.5 \pm 0.07$ & $11.8 \pm 0.16$ & $9.80 \pm 0.05$ & $1.15 \pm 0.008$ \\
\hline 4 & Metacentric & $6.5 \pm 0.26$ & $5.3 \pm 0.07$ & $11.8 \pm 0.16$ & $9.80 \pm 0.05$ & $1.23 \pm 0.008$ \\
\hline 5 & Metacentric & $5.0 \pm 0.05$ & $5.5 \pm 0.06$ & $10.5 \pm 0.12$ & $8.72 \pm 0.15$ & $0.91 \pm 0.041$ \\
\hline 6 & Submetacentric & $5.0 \pm 0.05$ & $3.2 \pm 0.05$ & $8.2 \pm 0.10$ & $6.81 \pm 0.13$ & $1.56 \pm 0.022$ \\
\hline 7 & Submetacentric & $5.2 \pm 0.16$ & $3.0 \pm 0.04$ & $8.2 \pm 0.11$ & $6.81 \pm 0.13$ & $1.73 \pm 0.014$ \\
\hline 8 & Submetacentric & $4.0 \pm 0.05$ & $2.2 \pm 0.03$ & $6.2 \pm 0.07$ & $5.15 \pm 0.12$ & $1.82 \pm 0.011$ \\
\hline 9 & Submetacentric & $4.2 \pm 0.04$ & $2 \pm 0.03$ & $6.2 \pm 0.08$ & $5.15 \pm 0.12$ & $2.10 \pm 0.011$ \\
\hline 10 & Acrocentric & $4.0 \pm 0.04$ & $1.5 \pm 0.07$ & $5.5 \pm 0.11$ & $4.57 \pm 0.06$ & $2.67 \pm 0.012$ \\
\hline 11 & Acrocentric & $4.0 \pm 0.04$ & $1.3 \pm 0.06$ & $5.3 \pm 0.13$ & $4.40 \pm 0.04$ & $3.08 \pm 0.14$ \\
\hline 12 & Acrocentric & $3.0 \pm 0.01$ & $1.2 \pm 0.04$ & $4.2 \pm 0.05$ & $3.49 \pm 0.16$ & $2.50 \pm 0.07$ \\
\hline 13 & Telocentric & $4.1 \pm 0.05$ & 0 & $4.1 \pm 0.05$ & $3.41 \pm 0.15$ & -- \\
\hline 14 & Telocentric & $3.2 \pm 0.03$ & 0 & $3.2 \pm 0.14$ & $2.66 \pm 0.08$ & --- \\
\hline 15 & Telocentric & $3.4 \pm 0.04$ & 0 & $3.4 \pm 0.13$ & $2.82 \pm 0.01$ & --- \\
\hline 16 & Telocentric & $3.4 \pm 0.05$ & 0 & $3.4 \pm 0.13$ & $2.82 \pm 0.01$ & --- \\
\hline 17 & Telocentric & $2.5 \pm 0.03$ & 0 & $2.5 \pm 0.05$ & $2.08 \pm 0.01$ & --- \\
\hline 18 & Telocentric & $2 \pm 0.002$ & 0 & $2.0 \pm 0.04$ & $1.66 \pm 0.01$ & --- \\
\hline
\end{tabular}

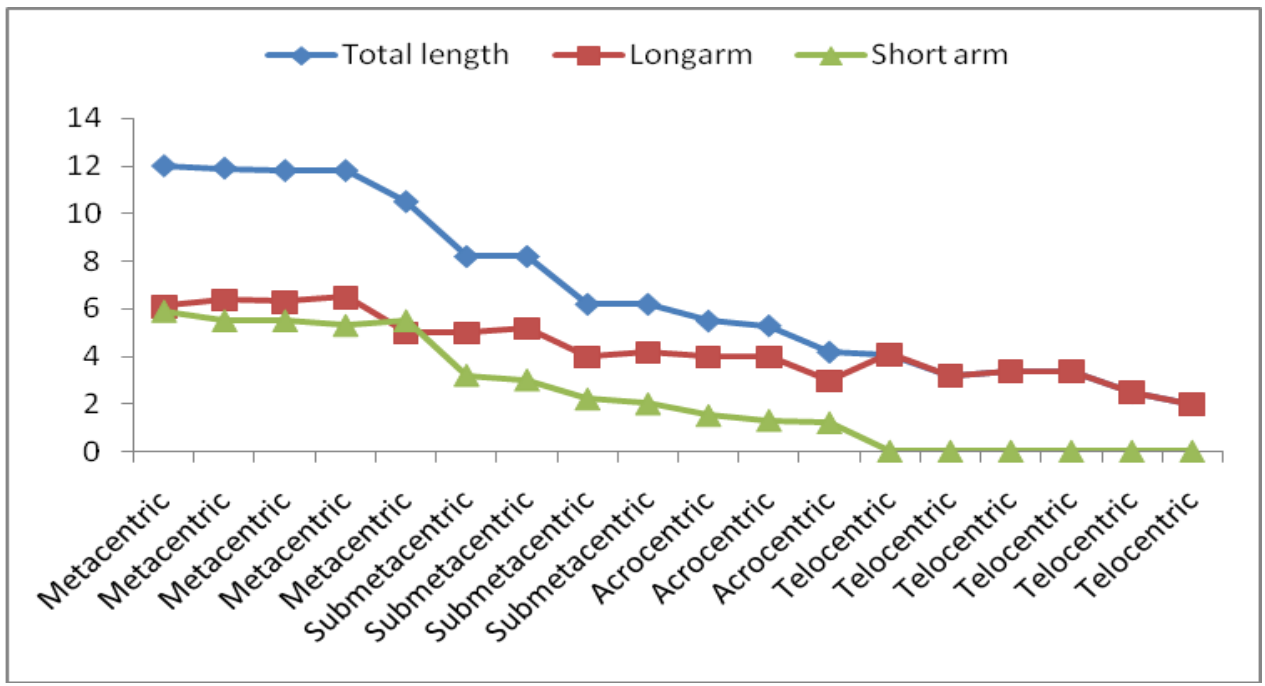

Fig. 2. Classification of haploid chromosomes $(n=18)$ of Biomphalaria alexandrina. 
A

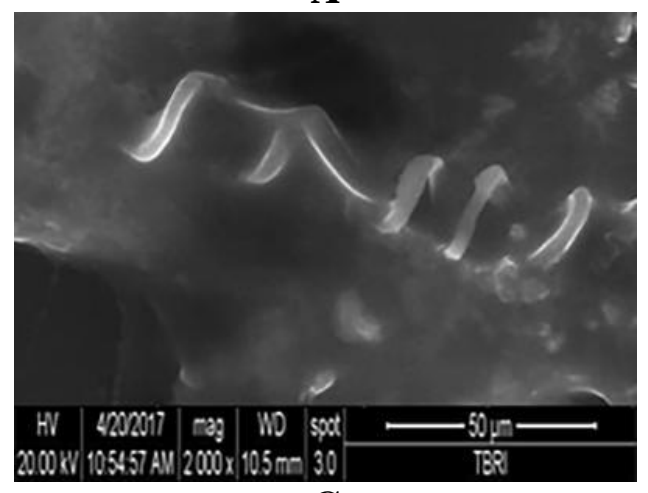

C

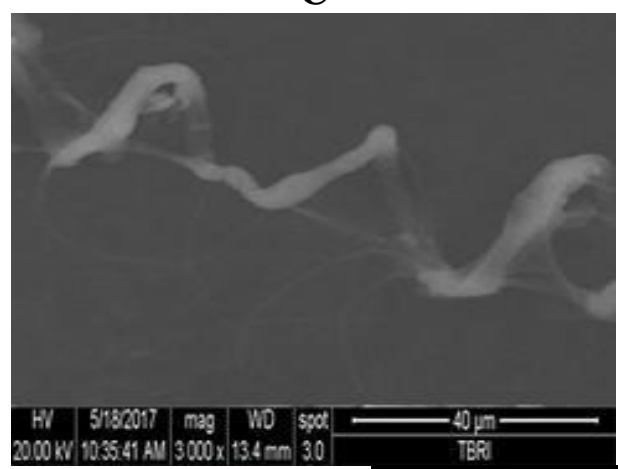

B

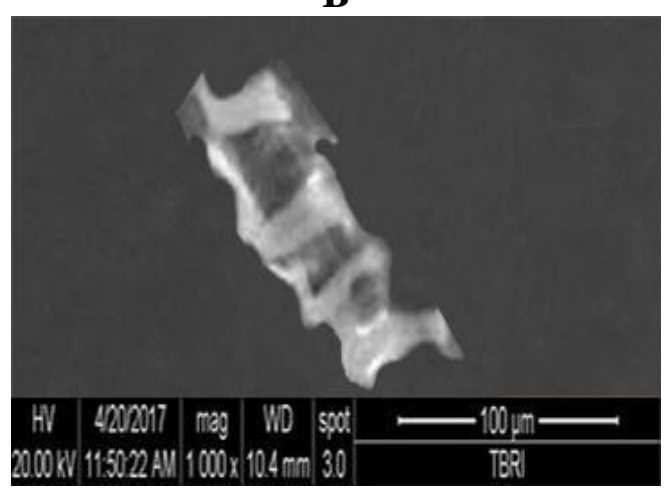

D
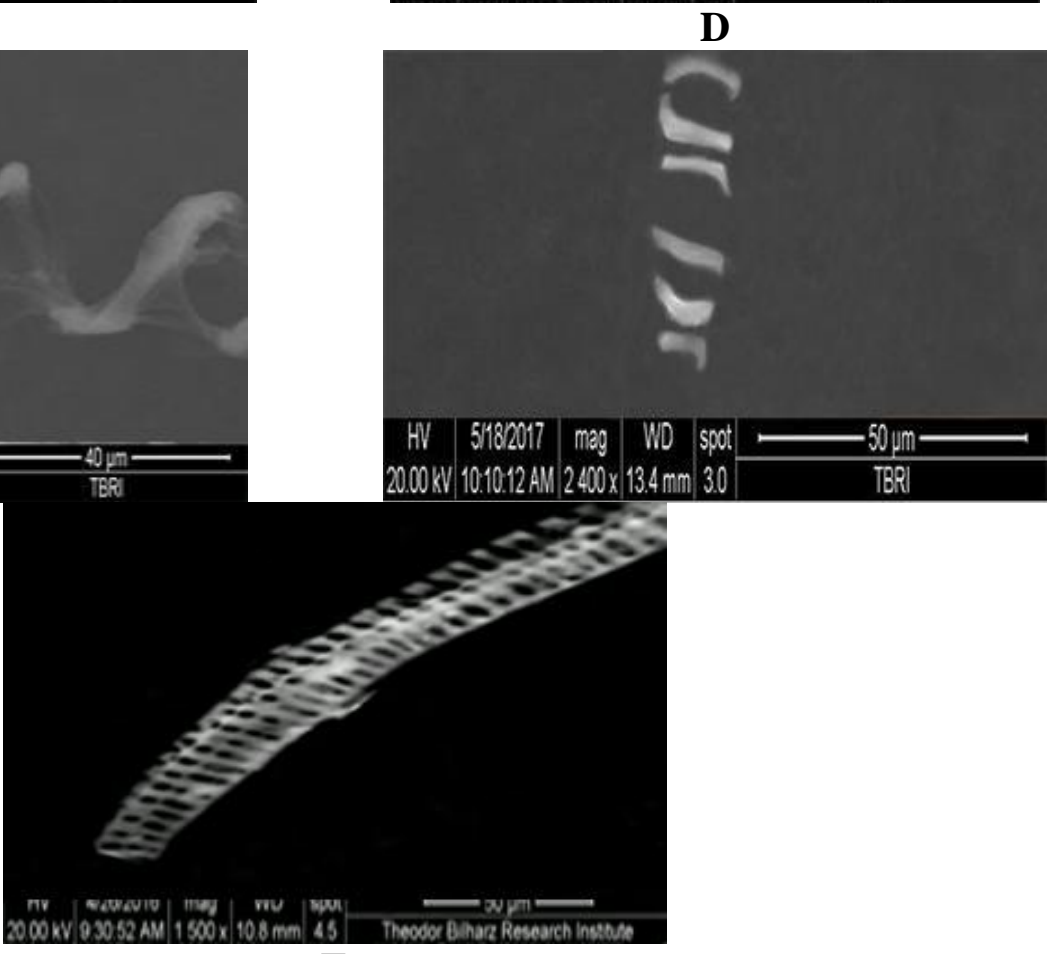

$\mathbf{E}$

Fig. 3. Scanning Electron micrograph of Biomphalaria alexandrina chromosomes showing variation in length. A: Length varies from 12 to $10.5 \mu \mathrm{m}$ (metacentric). B: Length varies from 8.2 to $6.2 \mu \mathrm{m}$ (submetacentric). C: Length varies from 5.5 to $4.2 \mu \mathrm{m}$ (acrocentric). D: Length varies from 4.1 to $2 \mu \mathrm{m}$ (telocentric). E: The chromosomes start as metacentric in the $1^{\text {st }}$ chromosome then the centromer shifts to the terminal end gradually with the decrease in the length of the chromosomes until the eighteen chromosomes.

\section{DISCUSSION}

The present work is the first chromosomal study of B. alexandrina snails done by using transmission and environmental scanning electron microscope. EM enables imaging of cells and tissues with high-resolution analysis (Wanner et al., 2000). The processing of cells for conventional high vacuum SEM leads to the loss of morphological features that are retained when using ESEM which can be used to look at chromosomes 
in their entirety; ESEM has the advantage that wet specimens can be examined in their native form without being dehydrated and not require conductive coating. It is especially useful for biological specimens and other specimens containing water (McKinlay et al., 2004).

The freshwater snails of the genus $B$. alexandrina are the most common snail prevailing in developing countries and play a potential role in transmission of $S$. mansoni (Toor et al., 2018). The present work deal with the chromosomal study of B.alexandrina snails by using electron microscope techniques which include (TEM) and (ESEM) microscopy. These techniques provide higher resolution than that of light and fluorescence microscopy. In addition uranyl acetate $\left(\mathrm{UO}_{2}\left(\mathrm{CH}_{3} \mathrm{COO}\right)_{2}\right)$ and $\left(\mathrm{OsO}_{4}\right)$ used are heavy metal stains that are widely used in studying biological samples with electron microscopy are known to scatter electrons well and adsorb to biological matter easily (Hayat, 2000 and Verma, 2001).

High resolution scanning electron microscope has proven to be an appropriate tool for investigating chromatin ultrastructure of human, Drosophila and plant chromosomes (Allen et al., 1988; Sumner, 1991 and Wanner et al., 1991), but light and fluorescence microscopy both have limited resolution thus, they provide little information. The advantage of light microscopy has a little damage on the chromosomes while the advantage of fluorescence microscopy has a high sensitivity and specificity (Rost, 1992).

The present results revealed that the diploid chromosomes number of $B$. alexandrina is 36. These results are in agreement with Ibrahim et al. (2018) and the results of several studies approving the karyotypes of the fresh-water snails and support the present work. From which, Raghunathan, (1976) who studied karyotype in $B$. glabrata found that diploid chromosome number is $2 \mathrm{~N}=36$. Also, Goldman et al. (1980 \&1983) and Brown et al. (1996) studied the karyotype of Bulinus trancatus and B. tropicus (Planorbidae) and they found that diploid chromosome number is $2 \mathrm{~N}=36$. Bakry and El Garhy, (2011) detected the karyotypes of B. alexandrina and Bulinus truncats, the two species have the same diploid chromosome number $2 \mathrm{n}=36$. The current results are also in agreement with Abdel-Haleem (2013), who reported that the diploid number $2 \mathrm{~N}$ in B. alexandrina and B. glabrata were 36. Also, Park and Yong, (2014) found that the diploid chromosome number is the same number in B.tengophila.

TEM examination allows studying of chromosomes stained with DAPI. The stained cells were examined by electron microscopy. We could detect the 4 different phases Interphase, prophase, metaphase and anaphase. The result of Zoller $\boldsymbol{e t}$ al. (2004) found remarkable differences during chromosome condensation in mitosis and meiosis in different phase by SEM. In addition to Tohamy and Mohamed (2006) and Ibrahim et al. (2018) who found that the first meiotic division begins with a long prophase which is subdivided into four stages, leptotene, zygotene, pachytene, and diplotene by light microscopy.

In the present study we measured the lengths of chromosomes by ESEM. The measurement of the eighteen chromosomes were arranged between $12 \mu \mathrm{m}$ and $2 \mu \mathrm{m}$ while Abdel-Haleem (2013) who detected the length of eighteen chromosomes by LM in $B$. glabrata and $B$. alexandrina between $4.50 \mu \mathrm{m}\left(1^{\mathrm{st}}\right.$ chromosome $) \& 1.35 \mu \mathrm{m}\left(18^{\text {th }}\right.$ chromosome) and $4.22 \mu \mathrm{m}$ ( $1{ }^{\text {st }}$ chromosome $) \& 0.9 \mu \mathrm{m}\left(18^{\text {th }}\right.$ chromosome $)$ respectively. 
In addition Park and Yong (2014) detected the length of eighteen chromosomes ranging between $6.4 \mu \mathrm{m}$ ( $1^{\text {st }}$ chromosome $)$ and $2.4 \mu \mathrm{m}\left(18^{\text {th }}\right.$ chromosome $)$ by LM in B.tengophila.

The present results showed four types of chromosomes in B. alexandrina 5 metacentric, 4 submetacentric, 3 acrocentric and 6 telocentric. As we see the chromosomes start as metacentric in the $1^{\text {st }}$ chromosome then the centromer shifts to the terminal end gradually with the decrease in the length of the chromosomes until the eighteen chromosomes. The results of Raghunathan (1976) who detected that chromosome pairs are classified into 4 groups; 10 pairs metacentric, 4 pairs submetacentric, 2 pairs acrocentric and 2 pairs telocentric chromosomes in B. glabrata. In addition to Tohamy and Mohamed (2006) found that the mitotic chromosomes of Bithynia snails were six metacentric pairs, four submetacentric, three subtelocentric and three telocentric chromosomes. Bakry and El Garhy (2011) classified the chromosome according of centromere position in $B$. alexandrina to 8 metacentric pairs, 8 submetacentric pairs and 2 subtelocentric pairs of chromosomes while, the karyotype of B. truncatus is organized in four groups and consists of 10 metacentric pairs, 4 submetacentric pairs, 2 telocentric pairs and 2 subtelocentric pairs of chromosomes. Abdel-Haleem (2013) who found four types of chromosomes in B. glabrata and B. alexandrina; 10 metacentric, 4 submetacentric, 2 acrocentric and 2 telocentric in each one. Also, Park and Yong (2014) detected that 18 chromosome pairs were classified into 3 groups; 7 pairs metacentric, 8 pairs submetacentric and 3 pairs subtelocentric chromosomes in B.tengophila.

These results on chromosomal study open the door to the initiation of further experiments in this field of research, using ESEM in variations amongst different snails, plays a crucial role in taxonomy.

\section{CONCLUSION}

The present work is the first chromosomal study of B. alexandrina snails by using Transmission and Scanning Electron Microscope and clarified the four meiotic divisions and four types of chromosomes: 5 pairs of metacentric, 4 pairs of submetacentric, 3 pairs of acrocentric and 6 pairs of telocentric with wide variation in length (12- $2 \mu \mathrm{m})$. So high resolution ESEM has proven to useful tool for chromosomal study.Chromosomal pattern that may be useful for breaking the host parasite relationship.

\section{REFERENCES}

Abdel-Haleem, A.A. (2013). Comparative karyological studies on the two Egyptian schistosome vectors, Biomphalaria glabrata and Biomphalaria alexandrina, with reference to chromosomal aberrations due to Za'ater plant. Inter. J. Academic Sci. Res. 1: 1-7.

Allen, T.D.; Jack, E.M. and Harrisonc, J. (1988). The three dimensional structure of human metaphase chromosomes determined by scanning electron microscopy, Adolph KW (ed): Chromosomes and Chromatin,vol II, pp 51-72 (CRC Press, Boca Raton). 
Bakry, F.A. and Garhy, M.F. (2011). Comparative study of the karyotypes and electrophoretic patterns of Biomphalaria alexandrina and Bulinus truncatus and the ova of their corresponding trematode hosts. J. Evol. Biol. Res. 3: 22-28.

Barsiene, J.; Ribbi, G. and Barsyte, D. (2000). Comparative karyological analysis of five species of viviparus (gastropoda: prosobranchia). J. Mollu. Stud. 66(2):259-271.

Brown, D. S.; Curtis, B.A. and Rollinson, D. (1996). The freshwater snail Bulinus tropicus (Planorbidae) in Namibia, characterized according to chromosome number enzymes and morphology. Hydrobiologia, 317: 127-139.

CDC, (2018). Schistosomiasis - Biology [WWW Document]. URL https://www.cdc.gov/ parasites/schistosomiasis/index.html (accessed 4.29.19).

Colley, D.G.; Bustinduy, A.L.; Secor, W.E. and King, C.H. (2014). Human schistosomiasis. Lancet, 383:2253-2264.

El-Sheikh, Y.W.A.; Eltamny, H.M. and Soliman, H.A. (2012). Molluscicidal activity of ecofriendly natural compound (Rutin) gained from ethanolic flowers extract of Calendula officinalis on Biomphalaria alexandrina,. Bulinus truncatus and Lymnaea s.p snails. NY. Sci. J. 5:19-27.

Glauert, A. M. (1974). The high voltage electron microscope in biology. J. Cell. Boil. 63: 717-748.

Goldman, M.A.; Loverde, P.T.; and Chrisman, C. L.(1983). Comparative karyology of the freshwater snails Biomphalaria glabrata (Mollusca: Planorbidae). Can. J. Genet.Cytol. 22: 361-367.

Goldman, M.A.; Philip, T.; Loverde, C. and Chrisman, L.(1980). Hybrid origin of polyploidy in freshwater snails of Bulinus tropicus and Lymnaea natalensis. (Mollusca: Planorbidae). Evo. 37: 592-600.

Gryseels, B.; Polman, K.; Clerinx. J. and Kestens, L. (2006). Human schistosomiasis. The Lancet, 368: 1106-1118.

Hamta, A.; Adamovic, T.; Samuelson, E.; Helou, K.; Behboudi A., and Levan, G. (2006). Chromosome ideograms of the laboratory rat (Rattus norvegicus) based on highresolution banding, and anchoring of the cytogeneticmap to the DNA sequence by FISH in sample chromosomes. Cytogenet Genome Res. 115 :158-68.

Hayat, M.A.(2000). Principles and Techniques of Electron Microscopy: Biological applications: Cambridge University Press.

Ibrahim, A.M.; Hammam, O. A. and El-Dafrawy, S. M. (2018). Infected Freshwater Snails, Biomphalaria alexandrina, The Intermediate Host of Schistosoma mansoni J. Egypt. Soc. Parasit 48: 503 - 507.

McKinlay, K.; Allison, F.J.; Scotchford, C.; Grant, D.M.; Oliver, J.M.; King, J.R.; Wood, J.V. and Brown, P.D. (2004). Comparison of environmental scanning electron microscopy with high vacuum scanning electron microscopy as applied to the assessment of cell morphology. J. Biomed Mater Res. A. 69(2):359-366. 
Odoemelam, E.C.(2009). Genomic analysis of the fresh water mollusk Biomphalaria glabrata to understand host: parasite interactions. Ph.D. thesis. Brunel University, UK., pp 242.

Park, M. G. and Yong, S .T. (2014). Karyological Studies of Biomphalaria tenagophila (d'Orbigny, 1835) (Gastropoda: Planobidae) from Rio de Janeiro, Brazil Korean J. Parasit. 52: 449-451.

Raghunathan, L. (1976). The karyotype of Biomphalaria glabrata, the snail vector of Schistosoma mansoni. Malacologia, 15 : 447-450.

Rost, F.W.D. (1992). The optical system of the fluorescence microscope, in Fluorescence Microscopy, vol. 1. Cambridge University Press, Cambridge, UK, 35-63.

Szabelska, A.; Juchno, D.; Spóz, A. and Boron, A. (2015). Mitotic and meiotic chromosomes of the Great Rams Horn Snail Planorbarius corneus (Linnaeus, 1758) (Gastropoda, Planorbidae) from Lake Kortowskie. Polish J. Nat., Sci. 30: 47-57.

Sumner, A.T. (1991). Scanning electron microscopy of mammalian chromosomes from prophase to telophase. Chromosoma, 100:410-418.

Thiriot-Quiévreux, C. (2003).Advances in chromosomal studies of gastropod mollusks. J. Mol. Stu . 69: 187-201.

Tohamy, A. A. and Mohamed S .M. (2006). Chromosomal studies on two Egyptian freshwater snails, Cleopatra and Bithynia (Mollusca-Prosobranchiata) Arab J. Biotech. 9:17-26.

Toor, J.; Alsallaq, R.; Truscott, J.E.; Turner, H.C.;Werkman, M.; Gurarie, D.; King, C.H. and erson R.M. ( 2018). Are We on Our Way to Achieving the 2020 Goals for Schistosomiasis Morbidity Control Using Current World Health Organization Guidelines? Clin. Infect. Dis. 66: S245-S252.

Verma, G.P. (2001). Fundamentals of Histology: New Age International (P) Ltd.

Wanner, G.; Formanek, H.; Martin, R. and Herrmann, R.G. (1991). High resolution scanning electron microscopy of plant chromosomes. Chromosoma, 100:103-109.

Wanner, G. and Formanek, H. (2000). A new chromosome model. J. of structural biology, 132(2): 147-161.

WHO. (2020). Schistosomiasis, Fact Sheets https://www.who.int/news-room/factsheets/detail/Schistosomiasis, 2020 updated 2 March, 2020

Zoller, J.F.; Hohmann, U.; Herrmann, R.G. and Wanner, G. (2004). Chromosome condensation in mitosis and meiosis of rye (Secale cereale L.). Cytogenet. Genome Res. 105:134-144. 


\section{ARABIC SUMMARY \\ دراسات كروموسومية على قواقع Biomphalaria alexandrina باستخدام الميكروسكوب الإكتروني الماستح والنافذ \\ سماح ابراهيم غنيم' ــ اميرة محمد حلمي؟ ـ شادية محمد الدفراوي' \\ قسم بحوث البيئة و الرخويات الطبية' ـ الميكروسكوب الإلكتروني` بمعهد تيودور بلهارس للأبحاثـ مصر}

تم فحص النمط الكروموسومي لقو اقع Biomphalaria alexandrina وذللك قد يكون مفيدًا لكسر علاقة الطفيلي بالعائل الوسيط وقد تم ذللك بدر اسة كروموسومات هذه القو اقع ـ وتعتبر قو اقع المياه العذبة كعائل وسيط للطفيلي لإني وضروري لانتقال مرض وفة البلارسيا.

$$
\text { و الهدف من هذه الدر اسة توضيح مر احل الانقسام الميتوزي الأربعة التي تبدأ }
$$

Interphase, prophase, metaphase and anaphase.

عن طريق الميكروسكوب الإلكتروني النافذ. وقد تم قياس أطوال الكروموسومات بو اسطة الميكروسكوب الإلكتروني

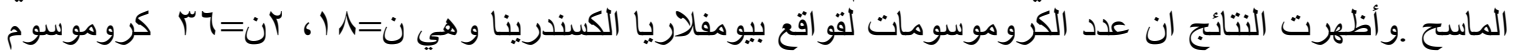

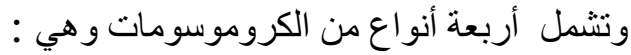

5 metacentric pairs, 4 submetacentric pairs, 3 acrocentric pairs and 6 telocentric pairs chromosomes.

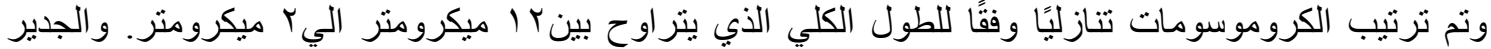

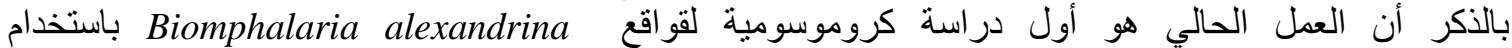
الميكروسكوب إلكتروني النافذ و الماسح. 